\title{
FLUOXETINE USE IS ASSOCIATED WITH IMPROVED SURVIVAL OF PATIENTS WITH COVID-19 PNEUMONIA: A RETROSPECTIVE CASE-CONTROL STUDY
}

\author{
Zsófia Klára NÉMETH', Anna SZÚCS², József VITRAI', Dóra JUHÁSZ1, \\ János Pál NÉMETH ${ }^{4}$, András HOLLÓ 5
}

\begin{abstract}
14th Department of Internal Medicine, Uzsoki Street Teaching Hospital of the Semmelweis University, Budapest ${ }^{2}$ Department of Behavioural Sciences, Semmelweis University, Budapest

${ }^{3}$ Independent expert, Budapest

${ }^{4}$ Department of Management, Budapest Business School, Budapest ${ }^{5}$ Tündérhegy Dept. of Psychosomatics and Psychotherapeutic Rehabilitation, National Institute of Medical

Rehabilitation, Budapest
\end{abstract}

()

Background and purpose - We aimed to investigate the association between fluoxetine use and the survival of hospitalised coronavirus disease (COVID-19) pneumonia patients. Methods - This retrospective case-control study used data extracted from the medical records of adult patients hospitalised with moderate or severe COVID-19 pneumonia at the Uzsoki Teaching Hospital of the Semmelweis University in Budapest, Hungary between 17 March and 22 April 2021. As a part of standard medical treatment, patients received anti-COVID-19 therapies as favipiravir, remdesivir, baricitinib or a combination of these drugs; and 110 of them received $20 \mathrm{mg}$ fluoxetine capsules once daily as an adjuvant medication. Multivariable logistic regression was used to evaluate the association between fluoxetine use and mortality.

For excluding a fluoxetine-selection bias potentially influencing our results, we compared baseline prognostic markers in the two groups treated versus not treated with fluoxetine. Results - Out of the 269 participants, 205 (76.2\%) survived and 64 (23.8\%) died between days 2 and 28 after hospitalisation. Greater age (OR [95\% Cl] 1.08 [1.05-1.11], $p<0.001$ ), radiographic severity based on chest $X$-ray (OR [95\% Cl] 2.03 [1.27-3.25], $p=0.003$ ) and higher score of shortened National Early Warning Score (sNEWS) (OR [95\% $\mathrm{Cl}] 1.20$ [1.01-1.43], $p=0.04$ ) were associated with higher mortality. Fluoxetine use was associated with an important (70\%) decrease of mortality (OR [95\% Cl] 0.33 [0.16-0.68], $\mathrm{p}=0.002)$ compared to the non-fluoxetine group. Age, gender, LDH, CRP, and D-dimer levels, sNEWS, Chest X-ray

\author{
A FLUOXETINT SZEDÓ COVID-19-PNEUMONIÁS \\ BETEGEKNEK NAGYOBB A TÚLÉLÉSI ESÉLYE: \\ RETROSPEKTÍV, ESET-KONTROLLOS VIZSGÁLAT \\ Németh ZsK, MD; Szúcs A; Vitrai J; Juhász D, MD; \\ Németh JP, Holló A, MD
}

Ideggyogy Sz 2021;74(11-12):389-396.

Háttér és cél - Van-e összefüggés a fluoxetinszedés és a kórházban kezelt közepesen súlyos/súlyos COVID-19. pneumonia túlélése között?

Módszerek - A Semmelweis Egyetem Uzsoki Utcai Gyakorló Kórházában 2021. március 17. és április 22. között kezelt személyek orvosi dokumentációja alapián retrospektív eset-kontroll vizsgálatot végeztünk. A betegek a standard belgyógyászati kezelés mellett anti-COVID-19 kezelésben (favipiravir, remdesivir, baricitinib, vagy ezek kombinációi) részesültek. 110 fő ezenfelül napi 20 mg fluoxetint is kapott. A mortalitás és a fluoxetinszedés összefüggésének statisztikai elemzésére többváltozós logisztikus regressziót alkalmaztunk. Annak ellenőrzésére, hogy eredményeinket nem befolyásolhatta-e szelekciós hiba (fluoxetine selection bias), összehasonlítottuk a fluoxetinnel kezelt és nem kezelt két betegcsoport kórházi felvételi klinikai, radiológiai és laboratóriumi prognosztikai jellemzőit. Eredmények - A 269 vizsgált személy közül 205-en $(76,2 \%)$ maradtak életben, és 64-en $(23,8 \%)$ hunytak el a felvételt követő 2 . és 28 . nap között. A fluoxetint szedő csoport mortalitása jelentősen, $70 \%$-kal alacsonyabb - vagyis körülbelül harmadannyi - volt, mint a fluoxetint nem szedók mortalitása. Ez a hatás, függetlenül minden más, a mortalitást befolyásoló tényezótől, statisztikailag szignifikáns volt $(\mathrm{OR}[95 \% \mathrm{Cl}]$ 0,33 [0,16-0,68], $p=0,002)$. Sem az életkor és a nem, sem a kórházi felvételi C-reaktív protein, LDH- és D-dimer-szint, sem a shortened National Early Warning Score pontszám és

Correspondent: Dr. András HOLLÓ, Tündérhegy Department of Psychosomatics and Psychotherapeutic Rehabilitation, National Institute of Medical Rehabilitation; 1121 Budapest, Szanatórium u. 19.

E-mail: andras.hollo.flx@gmail.com

https://orcid.org/0000-0001-8855-0469

Érkezett: 2021. szeptember 24. Elfogadva: 2021. október 25. 
score did not show statistical difference between the fluoxetine and non-fluoxetine groups supporting the reliability of our finding.

Conclusion - Provisional to confirmation in randomised controlled studies, fluoxetine may be a potent treatment increasing the survival for COVID-19 pneumonia.

Keywords: fluoxetine, COVID-19, SARS-CoV-2, pneumonia, survival, mortality a mellkasröntgen súlyossági pontszám, illetve az első 48 órában végzett mellkas-CT-vizsgálatok aránya nem mutatott statisztikai különbséget a fluoxetint szedő és fluoxetint nem szedő két csoport között, alátámasztva a vizsgálati eredmény validitását.

Következtetés - Amennyiben ezt az eredményt, a túlélés háromszorosára növekedését, randomizált, kontrollált vizsgálatok is megerősítik, a fluoxetin a COVID-19-pneumonia hatékony gyógyszere lehet.

Kulcsszavak: fluoxetin, COVID-19, SARS-CoV-2, pneumonia, túlélés, mortalitás
Nince the emergence of the coronavirus disease (COVID-19) pandemic, several drugs have been used to improve patient outcomes worldwide; however, the current armamentarium against COVID-19 remains suboptimal. Repurposing clinically well-established drugs might constitute a time-sparing method for improving pharmacotherapy of COVID-19'.

In spring 2021, the third COVID-19 wave culminated in Hungary, with a sad record of cases and deaths in that period ${ }^{2}$. A peak in mortality was experienced in the COVID-Centre of Uzsoki Hospital in Budapest, Hungary, too, severely distressing patients and medical teams. This extraordinary situation urged clinicians to induce new treatment strategies; e.g. introducing the antidepressant fluoxetine to the deeply worried and anxious COVID patients.

In one study, more than $40 \%$ of the population who were interviewed during the pandemic scored depressive or had anxiety symptoms ${ }^{3}$. Anxiety may compromise the immune system, which could result in an increased susceptibility to infection or increased disease severity ${ }^{4}$. This was evidenced in several medical conditions ${ }^{5-7}$. A meta-analysis revealed an association between mood disorders and increased COVID-19 mortality ${ }^{8}$. The anxiety levels of patients in the acute phase of COVID-19 pneumonia were found similar to those of patients with myocardial infarction ${ }^{9}$. Based on those data and facing the growing number of COVID-19 fatality hardly helped by antiviral medicines, the hospital team ventured contributing an anti-anxiety/antidepressive treatment to the standard antiviral medicines.

In medical emergencies, benzodiazepines are first-line anxiolytic drugs; however, at higher doses, they carry a risk of respiratory depression and may have an immune-compromising effect: a significant association was shown between benzodiazepine use and increased mortality of community-acquired pneumonia ${ }^{10,11}$. Since selective serotonin reuptake inhibitors (SSRIs) are established drugs for the treatment of anxiety ${ }^{12}$, they could suitably substitute benzodiazepines. The generally expected 2-3 weeks delay of SSRIs' clinical effect might limit their use, however, based on a metaanalysis, SSRIs can be effective by the end of the first week after treatment onset ${ }^{13}$. Therefore, the initiation of SSRI therapy soon after hospitalisation may help improving anxiety and mood within the likely period of hospital stay. Fluoxetine is considered the most effective anxiolytic SSRI drug ${ }^{14}$ seeming therefore appropriate for treating anxiety and low mood in COVID-19 patients.

We aimed to assess the potential change of mortality associated to adjuvant fluoxetine treatment between days 2 and 24 after hospitalisation; analysing the data of those COVID-19 pneumonia patients receiving versus not receiving fluoxetine.

\section{Patients and methods}

To determine the potential impact of fluoxetine use on the mortality of COVID-19 patients, we reviewed the medical records and performed a retrospective analysis. The ethics committee of the hospital approved our study (Uzsoki Hospital IKEB No. 19-IK/2021).

PATIENTS

We reviewed the medical records of those patients more than 18-year-old who were admitted to the 
COVID-Centre between 17 March and 22 April 2021 , i.e. the culmination of the third wave of the pandemic. The inclusion criteria were the followings: Results of an antigen or polymerase chain reaction test that confirmed a severe acute respiratory syndrome coronavirus 2 (SARS-CoV-2) infection; Pneumonia indicated by chest X-ray or CT; Stay in the COVID-centre for longer than 48 hours; No prior anti-COVID-19 vaccination. The patients or their close family members (in critical cases) gave a general written informed consent.

\section{TREATMENT}

In the extraordinary circumstances of the pandemic, the clinical state of patients together with the changing availability of antiviral drugs, determined the treatment-choice. First, only favipiravir was accessible; whereas remdesivir could be administered just for a few critically ill patients. Later, due to its increasing availability, remdesivir became the main COVID-19 therapy, gradually contributed to by baricitinib, which was usually reserved for younger patients with severe COVID-19, due to its shortage.

The introduction of fluoxetine followed a similar pattern. Using or not using it, was initially the treating physicians' decision. Based on the favourable experiences - no clinically significant side-effects have occurred - it has become part of the local antiCOVID protocol. This real-world situation resulted in different anti-COVID-19 drug combinations, where remdesivir was combined with fluoxetine significantly more often than with the rest of the above mentioned drugs.

The anti-COVID-19 drug doses were the followings: Favipiravir: first and second dose, $1600 \mathrm{mg}$; third to tenth dose, $600 \mathrm{mg}$; Remdesivir: first dose $200 \mathrm{mg}$; second to fifth/tenth dose, $100 \mathrm{mg}$; Baricitinib: $4 \mathrm{mg}$ once daily for 10 days. Fluoxetine was administered in $20 \mathrm{mg}$ capsules once daily. Patient care was performed in accordance with standard medical guidelines, including dexamethasone and thrombosis-prophylaxis.

\section{PROGNOSTIC FACTORS}

Baseline routine blood investigations at admission included C-reactive protein (CRP) and lactate dehydrogenase (LDH) levels for all patients and Ddimer concentrations in the majority of the study population.

Based on medical records, we retrospectively applied a shortened National Early Warning Score (sNEWS) for assessing the initial clinical prognosis of each patient. It included heart rate, systolic blood pressure, oxygen saturation, temperature, consciousness, need or no need of oxygen supply. Since respiration rate, which is part of the original NEWS ${ }^{15,16}$, was not systematically documented, we could not take it in account.

Based on the documentation, two of the authors (AH and ASZ) have postscored the after-admission chest X-rays of each patient (CX-score). The score ranged from 1 to 3 according to the documented radiographic severity $(1=$ mild, $2=$ medium, $3=$ severe). The fact that a thoracic CT scan was or was not performed in the first 48 hours of hospitalisation was also recorded.

\section{STATISTICAL ANALYSIS}

To describe the case (deceased) and control (survivor) groups, we provide descriptive statistics for all variables that were examined. Continuous variables were tested for normality of distribution using the Shapiro-Wilk test. To check the comparability of the two groups, the Mann-Whitney U tests were applied to evaluate the differences between the patient groups. Pearson chi-square and Fisher's exact tests were performed to assess the association between categorical variables. Continuous variables are expressed as median (IQR).

Congruent with the goals of the study, the primary response variable was defined as mortality between hospital days 2 and 28. To explore the associations between the primary response variable and explanatory variables for characterising survivors and deceased, all variables with a possible effect on mortality (i.e. prognostic factors) were entered into a multivariable logistic regression model.

We introduced age, LDH, CRP, D-dimer, sNEWS and CX-score as continuous variables, gender and medications as categorical variables. The adjusted risks are expressed as odds ratios (ORs) with $95 \%$ confidence intervals [CIs]). Due to the relatively small number of patients, the Box-Tidwell test was performed to test that the relationships between the continuous predictor and their logit is linear. Two models were built. In the first step, all variables were analysed; in the second, to build the model a backward stepwise variable selection was applied. Moreover, the area under the receiver operating characteristic curve (ROC-AUC) were calculated to measure the efficiency of the models in distinguishing between survivors and the deceased. Statistical significance was set at $\mathrm{p}<0.05$. All statistical analyses were performed using IBM SPSS v23 (Armonk, New York, USA). 
Table 1. Patient characteristics and differences between survivors and deceased

\begin{tabular}{|lllll|}
\hline Baseline characteristics & All patients $(\mathrm{n}=269)$ & Survivors $(\mathrm{n}=205)$ & Deceased $(\mathrm{n}=64)$ & $\mathrm{p}$-value \\
\hline Age in years, median (IQR) & $66.0(52.5-74.5)$ & $63.0(50.0-72.0)$ & $74.5(66.25-80.00)$ & $<0.001$ \\
Sex, male, $\mathrm{n}(\%)$ & $147(54.6 \%)$ & $114(55.6 \%)$ & $33(51.6 \%)$ & 0.569 \\
Laboratory tests and clinical scores & $785.5(624.5-1040.75)$ & $772.0(630.5-1031.5)$ & $915.0(585-1073.0)$ & 0.308 \\
LDH IU/L median (IQR) & $108.9(59.4-170.4)$ & $106.5(57.9-159.7)$ & $137.0(62.5-192.5)$ & 0.035 \\
CRP mg/L median (IQR) & $0.47(0.29-0.92)$ & $0.41(0.28-0.79)$ & $0.61(0.37-1.56)$ & 0.002 \\
D-dimer $\mu$ g/L median (IQR) & $5(4-6)$ & $5(4-6)$ & $6(5-7)$ & $<0.001$ \\
sNEWS median (IQR) & $68(25.3 \%)$ & $54(26.3 \%)$ & $14(21.9 \%)$ & 0.514 \\
Chest CT performed $\mathrm{n}(\%)$ & $2(1-2)$ & $2(1-2)$ & $2(1-3)$ & 0.027 \\
CX-score median (IQR) & $124(46.1 \%)$ & $80(39.0 \%)$ & $44(68.8 \%)$ & $<0.001$ \\
Therapy received, $\mathrm{n}(\%)$ & $156(58.0 \%)$ & $133(64.9 \%)$ & $23(35.9 \%)$ & $<0.001$ \\
Favipiravir & $44(16.4 \%)$ & $37(18.0 \%)$ & $7(10.9 \%)$ & 0.18 \\
Remdesivir & $110(40.9 \%)$ & $95(46.3 \%)$ & $15(23.4 \%)$ & 0.001 \\
Baricitinib & & & & \\
Fluoxetine & & &
\end{tabular}

CRP: C-reactive protein, CX: Chest X-ray, LDH: lactate dehydrogenase, sNEWS: shortened National Early Warning Score

\section{Results}

Out of 623 patients admitted during the study period, 269 (147 males [54.6\%]; age, mean [range] 64.1 [19-96] years) were eligible for the study based on the inclusion criteria. A total of 205 patients survived $(76.2 \%)$ and 64 patients died $(23.8 \%)$ between days 2 and 28. None of the continuous variables (age, LDH, CRP, D-dimer, sNEWS and CX-score) were normally distributed in all subgroups (Shapiro Wilk $\min \left(\mathrm{p}_{\text {Survivors; }} \mathrm{p}_{\text {Deceased }}\right)<0.009$ és $\left.\min \left(\mathrm{p}_{\text {received fluoxetine: }} \mathrm{p}_{\text {not received fluoxetine }}\right)<0.035\right)$ therefore, the Mann-Whitney-Wilcoxon tests were applied.
We found significant intergroup differences in the age, CRP, and D-dimer, sNEWS, CX-score as well as in favipiravir, remdesivir, and fluoxetine use between the case and control groups (Table 1). Fluoxetine was administered to 110 patients (40.9\%). One patient developed severe hyponatraemia likely related to fluoxetine. Additional side effects possibly caused by fluoxetine included: increase in liver enzyme levels in one patient and confusion in another one. Fluoxetine was stopped in each case. Age, gender, LDH, CRP, and D-dimer levels, sNEWS, CX-score and the number of chest CT scans in the first 48 hours, did not show statistical difference between the fluoxetine and non-fluoxetine groups (Table 2).

Table 2. Characteristics of patients who did and did not receive fluoxetine

\begin{tabular}{|llll|}
\hline Characteristics & Received fluoxetine $(\mathrm{n}=110)$ & Did not receive fluoxetine $(\mathrm{n}=159)$ & $\mathrm{p}$-value \\
\hline Age in years, median (IQR) & $65.0(51.0-73.25)$ & $67.00(53.0-75.0)$ & 0.268 \\
Sex, male, $\mathrm{n}(\%)$ & $58(52.7 \%)$ & $89(56.0 \%)$ & 0.596 \\
Laboratory tests and clinical scores & & & \\
LDH IU/L median (IQR) & $821(638.3-1047.0)$ & $765.0(612.8-1030.0)$ & 0.327 \\
CRP mg/L median (IQR) & $108.5(56.6-174.0)$ & $107.7(60.1-164.5)$ & 0.940 \\
D-dimer $\mu \mathrm{g} / \mathrm{L}$ median (IQR) & $0.44(0.3-0.87)$ & $0.48(0.3-0.93)$ & 0.906 \\
sNEWS median (IQR) & $5(3.5-6)$ & $5(4-6)$ & 0.369 \\
Chest CT performed $\mathrm{n}(\%)$ & $33(30 \%)$ & $35(22 \%)$ & 0.155 \\
CX-score median (IQR) & $2(1-2)$ & $2(1-2)$ & 0.349 \\
Therapy received, $\mathrm{n}(\%)$ & & & \\
Remdesivir & $78(70.9 \%)$ & $78(49.1 \%)$ & $<0.001$ \\
Baricitinib & $34(30.9 \%)$ & $10(6.3 \%)$ & $<0.001$ \\
Favipiravir & $34(30.9 \%)$ & $90(56.6 \%)$ & $<0.001$ \\
Mortality in 2-28 days, $\mathrm{n}(\%)$ & $15(13.6 \%)$ & $49(30.8 \%)$ & 0.001 \\
\hline
\end{tabular}

CRP: C-reactive protein, CX: Chest X-ray, LDH: lactate dehydrogenase, sNEWS: shortened National Early Warning Score 
Table 3. Odds ratios for mortality calculated in a binary logistics model that included all variables

\begin{tabular}{|lllll|}
\hline Characteristics & $\beta$ & Wald & p-value & OR (95\% CI) \\
\hline Age (1 year) & 0.09 & 16.58 & $<0.001$ & $1.09(1.05-1.14)$ \\
Sex (reference=male) & -0.17 & 0.19 & 0.66 & $0.85(0.40-1.79)$ \\
Laboratory tests and clinical scores & & & & \\
LDH IU/L & 0.001 & 1.66 & 0.19 & $1.00(0.999-1.002)$ \\
CRP mg/L & 0.001 & 0.62 & 0.80 & $1.00(0.996-1.006)$ \\
D-dimer $\mu \mathrm{g} / \mathrm{L}$ & -0.002 & 0.0002 & 0.99 & $0.99(0.77-1.28)$ \\
sNEWS & 0.184 & 3.0 & 0.08 & $1.20(0.98-1.48)$ \\
Chest CT performed & -0.27 & 0.28 & 0.59 & $0.76(0.28-2.08)$ \\
CX-score & 0.715 & 6.5 & 0.01 & $2.05(1.18-3.55)$ \\
Medications & & & & \\
FAV (reference=not receiving) & 1.33 & 3.14 & 0.08 & $3.79(0.87-16.55)$ \\
Remdesivir (reference= not receiving) & 0.92 & 1.47 & 0.23 & $2.52(0.57-11.12)$ \\
Baricitinib (reference=not receiving) & 1.2 & 3.65 & 0.06 & $3.33(0.97-11.42)$ \\
Fluoxetine (reference=not receiving) & -1.32 & 9.17 & 0.002 & $0.27(0.11-0.63)$ \\
\hline
\end{tabular}

$\mathrm{N}=259$ (discharged from hospital $=201 ;$ deceased $=58$ )

Likelihood ratio test: $\chi^{2}=76.26 ; \mathrm{df}=12 ; \mathrm{p}<0.001$

Nagelkerke $R^{2}=0.39$

ROC-AUC $=0.84(95 \% \mathrm{Cl} 0.76-0.92)$

CRP: C-reactive protein, CX: Chest X-ray, LDH: lactate dehydrogenase, ROC-AUC: area under the receiver operating characteristic curve,

sNEWS: shortened National Early Warning Score

Table 4. Odds ratios for mortality calculated in a binary logistics model that included only significant variables after backward stepwise variable selection

\begin{tabular}{|lllll|}
\hline Characteristics & $\beta$ & Wald & p-value & OR $(95 \% \mathrm{CI})$ \\
\hline Age (1 year) & 0.078 & 28.29 & $<0.001$ & $1.08(1.05-1.11)$ \\
Fluoxetine (reference=not receiving) & -1.11 & 8.92 & 0.002 & $0.33(0.16-0.68)$ \\
CX-score & 0.71 & 8.87 & 0.003 & $2.03(1.27-3.25)$ \\
sNEWS & 1.82 & 4.06 & 0.044 & $1.20(1.01-1.43)$ \\
\hline
\end{tabular}

$\mathrm{N}=264$ (discharged from hospital $=204$; deceased $=60$ )

Likelihood ratio test: $\chi^{2}=65.254 ; \mathrm{df}=4 ; \mathrm{p}<0.001$

Nagelkerke $\mathrm{R}^{2}=0.33$

ROC-AUC $=0.81(95 \% \mathrm{Cl} 0.75-0.87)$

CRP: C-reactive protein, CX: Chest X-ray, ROC-AUC: area under the receiver operating characteristic curve, sNEWS: shortened National Early Warning Score

Only three variables showed a significant association with mortality: age, fluoxetine, and CX-score (Table 3). Variables that were found to be significantly associated with mortality in the regression analysis using backward selection are presented in Table 4. The results of the Box-Tidwell test were acceptable for both of the continuous variables (age, $\mathrm{p}=0.99$; sNEWS $\mathrm{p}=0.16$ ).

Patients on fluoxetine therapy were 0.33 times (95\% CI 0.16-0.68) less likely to die than those who had not received fluoxetine; i.e. the survival of patients in the fluoxetine group increased threefold. In addition, age increased the likelihood of death, wherein an increase of 1 year increased the OR by $8 \%$. The increased likelihood of death was also associated with the sNEWS, one unit increase in sNEWS increased the OR by $1.2(95 \% \mathrm{CI}$
1.01-1.43). The increased likelihood of death was also associated with the CX-score, one unit increase in the score increased the OR by 2.03 (95\% CI 1.27-3.25).

The final model explained one-third of the variance (Nagelkerke $\mathrm{R}^{2}=0.33$ ), and the distinguishing characteristics of the model were proven to be excellent (ROC-AUC $=0.81$ [95\% CI 0.75-0.87]).

\section{Discussion}

We found that fluoxetine use associated with a reduction of mortality to one third in patients with COVID-19 pneumonia. This finding was independent from the effect of the frequently co-administered remdesivir (Tables 2-4). 
In our study, age was a risk factor significantly influencing mortality. In agreement with other studies $^{17,18}$, the mortality risk increased by $8 \%$ with every 1 -year increase in age. In accordance with the literature attributing strong prognostic value to sNEWS and CX-score in COVID-19, also we found them predictive for mortality ${ }^{19,20}$.

No quantitative psychology tests could be performed in the busy period with critically ill and severely dyspnoeic patients, but the team did not experience any clinically relevant increases of anxiety at the initiation of SSRI in this group, unlike in some reports of the literature ${ }^{21}$. Some of the published data suggest a risk of bleeding with fluoxetine $^{22}$, and in addition, COVID-19 patients received low-molecular-weight heparin (LMWH) for thrombosis-prophylaxis in the COVID-19-related hypercoagulable state. One study that evaluated combination therapy with LMWH and SSRI, did not detect an increased incidence of major bleeding ${ }^{23}$. We paid special attention to this risk, which has not occurred in our patients. Hyponatraemia is another concern $^{24,25}$ and it developed in one patient who was treated with fluoxetine, thereby necessitating drug withdrawal.

We investigated the possibility of a fluoxetineselection bias that could have influenced our results. In other words, we tried to exclude a deliberate or unwitting allocation of patients by the treating physician for fluoxetine treatment e.g. based on severity. We found no significant differences between the groups that were or were not treated with fluoxetine; marking similar prognoses at baseline and supporting the validity of our finding.

The striking improvement of survival in patients with COVID-19 pneumonia who were treated with fluoxetine is intriguing. This effect might have been related to a non-specific "psycho-immunologic" effect of fluoxetine; or to its immunomodulatory, anti-inflammatory and antiviral features; or potentially, to an additional unknown factor. Several studies in the literature suggest specific anti-COVID-19 and anti-inflammatory properties of the SSRIs fluoxetine and fluvoxamine ${ }^{26-30}$. Most of these data have been obtained from in vitro studies, which reveal multiple mechanisms of action: (1) modulation of the endolysosomal host-virus interface ${ }^{31,32}$, (2) modulation of the IL-6-mediated cytokine production ${ }^{30,33}$, (3) a sigma-1 receptor agonist profile resulting in an anti-inflammatory effect ${ }^{34-36}$, (4) inhibition of lysosomal acid sphingomyelinase, and the resultant transformation of the biophysical properties of the plasma membrane to inhibit SARS-CoV-2 infection $^{37}$, and
(5) modulation of the endocytic trafficking of the SARS-CoV-2 spike protein ${ }^{38}$.

As Schloer notes, while the antiviral agent remdesivir acts directly on viral structures by interfering with the viral RNA-dependent RNA polymerase, fluoxetine targets the endolysosomal host-virus interface, i.e., the host factor in viral invasion. A host-directed drug might decrease the likelihood of drug resistance because profound changes would be required to allow viruses to replicate independently of essential host factors ${ }^{39}$.

In a multicentre retrospective observational study, a significantly reduced risk of intubation and death was observed in hospitalised COVID-19 patients who were treated with the SSRI or SNRI antidepressants escitalopram, fluoxetine, paroxetine, venlafaxine, or mirtazapine ${ }^{40}$. In another study, an analysis of the medical billing data of approximately 739,000 COVID-19 patients revealed that patients who were treated with antipsychotic drugs carrying a sigma-1 receptor agonist profile needed mechanical ventilation half as often than those who were treated with the non-sigma-1 receptor agonist antipsychotic drugs ${ }^{41}$. Finally, a double-blind randomised trial found no clinical deterioration in 80 COVID-19 outpatients who received fluvoxamine, whereas 6 patients in the placebo arm $(n=72)$ experienced clinical deterioration ${ }^{42}$.

Fluoxetine was generally well tolerated by the COVID-19 patients of this study, possibly related also to its low dose used. The daily 20 -mg fluoxetine used in this study, is the minimum effective antidepressant dose, far from the recommended peak dose (80mg). Higher doses might have an even stronger anti-COVID effect, too.

To our knowledge, this is the first inpatient clinical study exploring the impact of fluoxetine on the outcome of COVID-19 pneumonia, however, it has several limitations. The most important ones are the relatively small number of patients and the non-randomised, retrospective study design. We reassuringly corrected this aspect by comparing prognostic markers in the fluoxetine versus non-fluoxetine groups, showing similar prognoses. The single-centre design might have constituted another limitation, balanced by the large catchment area of the Uzsoki COVID department with a heterogeneous population of about three million people. The lack of proper psychiatric assessments, no anxiety or depression-scores taken, may be considered additional limitations.

Future research should clarify the mechanism of action of fluoxetine, its optimal dose, and a poten- 
tially similar effect of other SSRIs in COVID-19. Another direction for research might be the possible role of psychiatric drugs, i.e., a "psycho-immunologic" treatment in severe infections.

\section{Conclusion}

Due to the retrospective and real-world nature of the study, the strong association found between fluoxetine therapy and survival requires further investigations. Provisional to confirmation in randomised controlled studies, fluoxetine may be a potent treatment for COVID-19 pneumonia. Fluoxetine's favourable profile - oral route, low cost, easy availability and safety - might make it especially suitable.

\section{ACKNOWLEDGEMENTS}

The authors are grateful to Dr. Zoltán Járai and Zoltán Brys for their critical comments and valuable help.

FUNDING

This study received no funding.

DECLARATIONS OF INTEREST: None.

\section{REFERENCES}

1. Sultana J, Crisafulli S, Gabbay F, Lynn E, Shakir S, Trifirò $G$. Challenges for drug repurposing in the COVID-19 pandemic era. Front Pharmacol 2020;11:588654. https://doi.org/10.3389/fphar.2020.588654

2. World Health Organization. WHO Coronavirus (COVID19) Dashboard: Situation by Region, Country, Territory \& Area. https://covid19.who.int/table

3. Pérez-Cano HJ, Moreno-Murguía MB, Morales-López O, Crow-Buchanan $O$, English JA, Lozano-Alcázar J, et al. Anxiety, depression, and stress in response to the coronavirus disease-19 pandemic. Cir 2020;88:562-8. https://doi.org/10.24875/CIRU.20000561

4. Coughlin S. Anxiety and depression: linkages with viral diseases. Public Health Rev 2012;34: 92. https://doi.org/10.1007/BF03391675

5. Wang YH, Li JQ, Shi JF, Que JY, Liu JJ, Lappin JM, et al. Depression and anxiety in relation to cancer incidence and mortality: a systematic review and meta-analysis of cohort studies. Mol Psychiatry 2020;25(7):1487-99.

https://doi.org/10.1038/s41380-019-0595-X

6. Watkins LL, Koch GG, Sherwood A, Blumenthal JA, Davidson JR, O'Connor $C$, et al. Association of anxiety and depression with all-cause mortality in individuals with coronary heart disease. J Am Heart Assoc 2013;2(2):e000068. https://doi.org/10.1161/JAHA.112.000068

7. Doupnik SK, Mitra N, Feudtner C, Marcus SC. The Influence of Comorbid Mood and Anxiety Disorders on Outcomes of Pediatric Patients Hospitalized for Pneumonia. Hosp Pediatr 2016;6(3):135-42. https://doi.org/10.1542/hpeds.2015-0177

8. Vai B, Mazza M G, Delli Colli C, Foiselle M, Allen B, Benedetti $F$, et al. Mental disorders and risk of COVID-19related mortality, hospitalisation, and intensive care unit admission: a systematic review and meta-analysis. Lancet Psychiatry 2021. https://doi.org/10.1016/S2215-0366(21)00232-7.

9. Çăglar A, Kaçer I. Anxiety levels in patients admitted to the emergency department with myocardial infarction or COVID-19 pneumonia. Psychol Health Med. https://doi.org/10.1080/13548506.2021.1876893
10. Ely EW, Dittus RS, Girard TD. Point: should benzodiazepines be avoided in mechanically ventilated patients? Yes. Chest 2012;142:281-4. https://doi.org/10.1378/chest.12-1189.

11. Obiora E, Hubbard R, Sanders RD, Myles PR. The impact of benzodiazepines on occurrence of pneumonia and mortality from pneumonia: a nested case-control and survival analysis in a population-based cohort. Thorax 2013;68:163-70. https://doi.org/10.1136/thoraxjnl-2012-202374

12. Jakubovski E, Johnson JA, Nasir M, Müller-Vahl K, Bloch $M H$. Systematic review and meta-analysis: Dose-response curve of SSRIs and SNRIs in anxiety disorders Depress Anxiety 2019;36(3):198-212. https://doi.org/10.1002/da.22854

13. Taylor MJ, Freemantle N, Geddes JR, Bhagwagar Z. Early onset of selective serotonin reuptake inhibitor antidepressant action: systematic review and meta-analysis. Arch Gen Psychiatry 2006;63:1217-23. https://doi.org/10.1001/archpsyc.63.11.1217.

14. Baldwin D, Woods $R$, Lawson R, Taylor D. Efficacy of drug treatments for generalised anxiety disorder: systematic review and meta-analysis. BMJ 2011;342:d1199. https://doi.org/10.1136/bmj.d1199.

15. National Early Warning Score (NEWS) - RCP London. https://www.rcplondon.ac.uk

16. Royal College of Physicians. National Early Warning Score (NEWS) 2012.

17. Yanez ND, Weiss NS, Romand JA, Treggiari M. COVID-19 mortality risk for older men and women. BMC Public Health 2020;20:1742. https://doi.org/10.1186/s12889-020-09826-8.

18. Starke KR, Reissig D, Petereit-Haack G, Schmauder S, Nienhaus A, Seidler A. The isolated effect of age on the risk of COVID-19 severe outcomes: a systematic review with meta-analysis. medRxiv 2021. https://doi.org/10.1101/2021.05.27.21257909.

19. Colombo CJ, Colombo RE, Maves RC, et al. Performance analysis of the national early warning score and modified early warning score in the adaptive COVID-19 Treatment Trial Cohort Crit Care Explor 2021;3(7):e0474.

20. Larici A. Cicchetti G, Marano R, Bonomo L, Storto M. 
COVID-19 pneumonia: current evidence of chest imaging features, evolution and prognosis. Chin J Acad Radiol 2021;4;1-12.

https://doi.org/10.1007/s42058-021-00068-0

21. Brambilla P, Cipriani A, Hotopf M, Barbui C. Side-effect profile of fluoxetine in comparison with other SSRIs, tricyclic and newer antidepressants: a meta-analysis of clinical trial data. Pharmacopsychiatry 2005;38:69-77. https://doi.org/10.1055/s-2005-837806

22. Laporte S, Chapelle C, Caillet P, Beyens M N, Bellet F, Delavenne $X$, et al. Bleeding risk under selective serotonin reuptake inhibitor (SSRI) antidepressants: A meta-analysis of observational studies. Pharmacol Res 2017;118:19-32. https://doi.org/10.1016/j.phrs.2016.08.017.

23. Samuel NG, Seifert $C F$. Risk of bleeding in patients on fulldose enoxaparin with venous thromboembolism and selective serotonin reuptake inhibitors. Ann Pharmacother 2017; 51:226-31. https://doi.org/10.1177/1060028016677309.

24. Viramontes TS, Truong H, Linnebur SA. Antidepressantinduced hyponatremia in older adults. Consult Pharm 2016; 31:139-50. https://doi.org/10.4140/TCP.n.2016.139.

25. Lundström E, Isaksson E, Näsman $P$, Wester $P$, Mårtensson B, Norrving B, et al. Safety and efficacy of fluoxetine on functional recovery after acute stroke (EFFECTS): a randomised, double-blind, placebo-controlled trial. Lancet Neurol 2020;19:661-9. https://doi.org/10.1016/S1474-4422(20)30219-2.

26. Zimniak M, Kirschner L, Hilpert H, Geiger N, Danov O, Oberwinkler $H$, et al. The serotonin reuptake inhibitor fluoxetine inhibits SARS-CoV-2 in human lung tissue. Sci Rep 2021;11:5890. https://doi.org/10.1038/s41598-021-85049-0.

27. Khater SEd, El-khouly A, Abdel-Bar MH, Al-mahallawi $A M$, Ghorab DM. Fluoxetine hydrochloride loaded lipid polymer hybrid nanoparticles showed possible efficiency against SARS-CoV-2 infection. Pharmaceutics 2021;607: 121023. https://doi.org/10.1016/j.ijpharm.2021.121023

28. Fred SM, Kuivanen S, Ugurlu H, Casarotto PC, Levanov L, Saksela $K$, et al. Antidepressant and antipsychotic drugs reduce viral infection by SARS-CoV-2 and fluoxetine show antiviral activity against the novel variants in vitro. bioRxiv 2021. https://doi.org/10.1101/2021.03.22.436379

29. Dechaumes A, Nekoua MP, Belouzard S, Sane F, Engelmann I, Dubuisson J, et al. Fluoxetine can inhibit SARSCoV-2 in vitro. Microorganisms 2021;9:339. https://doi.org/10.3390/microorganisms9020339.

30. Creeden JF, Imami AS, Eby HM, Gillman C, Becker KN, Reigle $J$, et al. Fluoxetine as an anti-inflammatory therapy in SARS-CoV-2 infection. Biomed Pharmacother 2021; 138:111437. https://doi.org/10.1016/j.biopha.2021.111437.

31. Sukhatme VP, Reiersen AM, Vayttaden SJ, Sukhatme V. Fluvoxamine: a review of its mechanism of action and its role in COVID-19. Front Pharmacol 2021;12:652688. https://doi.org/10.3389/fphar.2021.652688.
32. Schloer S, Brunotte L, Goretzko J, Mecate-Zambrano A, Korthals N, Gerke V, et al. Targeting the endolysosomal host-SARS-CoV-2 interface by clinically licensed functional inhibitors of acid sphingomyelinase (FIASMA) including the antidepressant fluoxetine. Emerg Microbes Infect 2020;9:2245-55. https://doi.org/10.1080/22221751.2020.1829082

33. Hiles SA, Baker AL, de Malmanche T, Attia J. Interleukin6, C-reactive protein and interleukin-10 after antidepressant treatment in people with depression: a meta-analysis. Psychol Med 2012;42:2015-26. https://doi.org/10.1017/S0033291712000128.

34. Hashimoto $K$. Repurposing of CNS drugs to treat COVID19 infection: targeting the sigma-1 receptor. Eur Arch Psychiatry Clin Neurosci 2021;271:249-58. https://doi.org/10.1007/s00406-020-01231-x.

35. Rosen DA, Seki SM, Fernández-Castañeda A, Beiter $R M$, Eccles JD, Woodfolk JA, et al. Modulation of the sigma-1 receptor-IRE1 pathway is beneficial in preclinical models of inflammation and sepsis. Sci Transl Med 2019;11: eaau5266. https://doi.org/10.1126/scitranslmed.aau5266.

36. Safrany ST, Brimson JM. Are fluoxetine's effects due to sigma-1 receptor agonism. Pharmacol Res 2016;113:707-8. https://doi.org/10.1016/j.phrs.2016.05.031.

37. Carpinteiro A, Edwards MJ, Hoffmann M, Kochs G, Gripp $B$, Weigang $S$, et al. Pharmacological inhibition of acid sphingomyelinase prevents uptake of SARS-CoV-2 by epithelial cells. Cell Rep Med 2020;1:100142. https://doi.org/10.1016/j.xcrm.2020.100142.

38. Glebov $O$. Low-dose fluvoxamine modulates endocytic trafficking of SARS-CoV-2 spike protein: a potential mechanism for anti-COVID-19 protection by antidepressants bioRxiv 2021. https://doi.org/10.1101/2021.06.15.448391

39. Schloer S, Brunotte L, Mecate-Zambrano A, Zheng S, Tang $J$, Ludwig S, et al. Drug synergy of combinatory treatment with remdesivir and the repurposed drugs fluoxetine and itraconazole effectively impairs SARS-CoV-2 infection in vitro. Br J Pharmacol 2021;178:2339-50. https://doi.org/10.1111/bph.15418

40. Hoertel N, Sánchez-Rico M, Vernet R, Beeker N, Jannot $A S$, Neuraz A, et al. Association between antidepressant use and reduced risk of intubation or death in hospitalized patients with COVID-19: results from an observational study. Mol Psychiatry 2021. https://doi.org/10.1038/s41380-021-01021-4

41. Gordon DE, Hiatt J, Bouhaddou M, Rezelj V, Ulferts S, Braberg $H$, et al. Comparative host-coronavirus protein interaction networks reveal pan-viral disease mechanisms. Science 2020;370:eabe9403. https://doi.org/10.1126/science.abe9403

42. Lenze EJ, Mattar C, Zorumski CF, Stevens A, Schweiger J, Nicol GE, et al. Fluvoxamine vs placebo and clinical deterioration in outpatients with symptomatic COVID-19: a randomized clinical trial. JAMA 2020;324:2292-300. https://doi.org/10.1001/jama.2020.22760. 